\title{
Influence of Membrane Properties on Pineapple Wine Clarification and Fouling Behavior
}

\author{
Received in revised form 21 April 2005, accepted 22 April 2005 \\ W. Youravong ${ }^{1 *}$, M. Phukdeekhong ${ }^{2} \&$ P. Taksinpatanapong ${ }^{3}$ \\ ${ }^{1,2 \& 3}$ Membrane Science and Technology Research Center, Department of Food Technology, \\ Faculty of Agro-industry, Prince of Songkla University, Thailand, 90112
}

\begin{abstract}
The experiment was carried out to investigate the influence of membrane pore size and hydrophobicity on the quality of clarified pineapple wine and fouling characteristics, using stirred cell dead-end microfiltration. The test membranes were mixed cellulose acetate (MCE, pore size 0.45 and $0.22 \mu \mathrm{m}$ ), modified polyvinylidene fluoride (MPVDF, $0.22 \mu \mathrm{m}$ ) and polyethersulfone (PESF, $0.22 \mu \mathrm{m}$ ). It was found that all types of membrane successfully clarified the pineapple wine. The membrane pore size and hydrophobicity played an importance role in membrane fouling, both reversible and irreversible. Regarding the permeate flux and fouling, $0.45 \mu \mathrm{m} \mathrm{MCE} \mathrm{was} \mathrm{the} \mathrm{most}$ suitable for pineapple wine clarification. However, intensive organoleptic test with pilot scale would be needed.
\end{abstract}

Keywords : Wine, microfiltration, fouling, clarification, pineapple

\subsection{INTRODUCTION}

Clarification is an important process for wine manufacturing. It is known that colloid particles, microorganism and macromolecules presented in the fresh wine have to be partially or totally removed to improve their turbidity (so called clarification) by microfiltration process [1]. The most frequent membrane pore sizes used in wine microfiltration are 0.1 and $0.22 \mu \mathrm{m}$ for white wine and $0.22 \mu \mathrm{m}$ for red wine [2]. The major problem of wine microfiltration is the reduction of permeates flux due to membrane fouling and concentration polarization. It was found that polysaccharide and polyphenols play an importance role in the fouling of mineral and organic membrane respectively [3,4]. Membrane fouling during microfiltration by wine constituents is mainly irreversible due to the interaction between these constituents and membrane and between these constituents themselves. The surface of fouled membrane showed a thin layer, made of bacteria and organic matter [4]. Thus the membrane properties, wine constituents and operating condition are important factors affecting membrane fouling.

Traditionaily, most wines in the world market are made from grapes. Thailand and other countries in South East Asia are rich in tropical fruits and cereal, potentially used for producing wine. Their flavor and test are unique and different from those made from grapes. Nowadays, variety of tropical

\footnotetext{
*Correspondence to: W. Youravong (e-mail: wirote.@psu.ac.th)
} 
fruit wines can be found in the local and international market. Among them, pineapple wine is the most popular one. The constituents presented in pineapple wine may be different from those made from grapes. Most previous works were focused on the impact of processing condition and the interaction of multi-components in the wine making from grapes as a raw material. Thus, the aim of this present work is to investigate influence of membrane properties, including membrane pore size and hydrophobicity on the quality of clarified pineapple wine and fouling characteristics.

\subsection{MATERIALS AND METHODS}

\subsection{Fresh Pineapple Wine Preparation}

The fresh pineapple wine (white wine) was prepared in our bioprocess laboratory, made from fresh pineapple juice using Saccharomyces Serevisiae as a starter. It was fermented and kept at room temperature $\left(25-28^{\circ} \mathrm{C}\right)$ for six months before filtration, allowing the large particle $(>-5 \mu \mathrm{m})$ to precipitate. The chemical composition and physical properties of fresh wine were analyzed and shown in Table 1.

Table 1 Composition and physical properties of fresh pineapple wine

\begin{tabular}{llll}
\hline \multicolumn{2}{c}{ Chemical composition } & \multicolumn{2}{c}{ Physical properties } \\
\hline \% Alcohol & $10.8 \pm 0.7$ & Density $\left(25^{\circ} \mathrm{C}\right)(\mathrm{mg} / \mathrm{ml})$ & $997 \pm 1$ \\
Protein $(\mathrm{mg} / \mathrm{l})$ & $17.8 \pm 0.6$ & Viscosity $\left(25^{\circ} \mathrm{C}\right)(\mathrm{mPa} . \mathrm{s})$ & $1.41 \pm 0.01$ \\
Citric acid $(\%)$ & $0.25 \pm 0.02$ & $\mathrm{pH}$ & $3.3 \pm 0.0$ \\
Acetic acid (\%) & $0.06 \pm 0.00$ & Turbidity (absorbance at $340 \mathrm{~nm})$ & $1.43 \pm 0.00$ \\
Total soluble solid & & Color & \\
$\left({ }^{\circ}\right.$ Brix $)$ & $7.5 \pm 0.0$ & L (lightness) & $98.20 \pm 0.12$ \\
& & a (redness) & $-1.92 \pm 0.01$ \\
& & b (yellowness) & $6.36 \pm 0.03$ \\
Total solid $(\mathrm{mg} / \mathrm{ml})$ & $22.8 \pm 0.8$ & & \\
\hline
\end{tabular}

\subsection{Membranes}

For the experiment, four different microfiltration membranes from the same manufacturer (Millipore) were tested. They were mixed cellulose esters (MCE), modified polyvinylidene fluoride (MPVDF) and polyethersulfone (PESF). The pore size, hydraulic resistance of clean 'membrane and hydrophobicity are shown in Table 2.

Table 2 Microfiltration membrane properties

\begin{tabular}{llll}
\hline $\begin{array}{l}\text { Pore size } \\
(\mu \mathrm{m})\end{array}$ & \multicolumn{1}{c}{ Material } & $\begin{array}{c}\text { Membrane resistance } \\
\left(\boldsymbol{R}_{\boldsymbol{m}}, \mathbf{~ m}^{-\mathbf{1}}\right)\end{array}$ & Hydrophilicity \\
\hline 0.22 & Mixed cellulose esters(MCE) & $2.49 \pm 0.21 \times 10^{8}$ & Hydrophilic \\
0.22 & Modified polyvinylidene fluoride (MPVDF) & $2.31 \pm 0.22 \times 10^{8}$ & Hydrophilic \\
0.22 & Polyethersulfone(PESF) & $2.79 \pm 0.86 \times 10^{8}$ & Hydrophobic \\
0.45 & Mixed cellulose esters (MCE) & $5.71 \pm 1.12 \times 10^{6}$ & Hydrophilic \\
\hline
\end{tabular}




\subsection{Experimental Conditions}

The experiments were carried out using dead-end membrane filtration unit with $90 \mathrm{ml}$ of stirred cell and 2 liters of feed vessel holder. The flat sheet membrane diameter was $4.7 \mathrm{~cm}$, giving an effective filtration area of $16.9 \mathrm{~cm}^{2}$. New membranes were soak in distilled water for a few hours before being used and then the hydraulic resistance of clean membrane $\left(R_{m}\right)$ was determined. The filtration of fresh wine was performed at constant transmembrane pressure $(\Delta P) 200 \mathrm{kPa}$ and temperature $25^{\circ} \mathrm{C}$ without stirring and stopped when the steady flux obtained. All experiments were done in triplicate.

\subsection{Fouling Study}

\subsubsection{Determination of Cake Resistance and Cake Filtration Volume}

Basic equation for dead-end batch filtration with constant pressure can be expressed as the following $[5]$ :

$$
\frac{t}{V}+\left(\frac{\mu \alpha C_{s}}{A^{2}(\Delta P)}\right) \frac{V}{2}+\left(\frac{\mu}{A(\Delta P)}\right) R_{m}
$$

where $A$ is the membrane area, $V$ is the total volume of permeate (or filtrate) collected up to time $t$, $\alpha$ is the specific cake resistance, $C_{s}$ is the mass of solid per volume of filtrate, $\Delta P$ is the pressure drop over the membrane or transmembrane pressure, $\mu$ is the filtrate viscosity and $R_{m}$ is the hydraulic membrane resistance.

Since this equation is in a linear form $\left(t / V\right.$ versus $V$ ), the product of $\alpha C_{s}$ (directly linked to cake property) for each experiment was determined using the slope obtained. The cake filtration volume $\left(V_{c}\right)$ is the minimum volume of the filtrate, in which the cake begins to form on the top of membrane surface (see Figure 2 and detail in section 3.2).

\subsubsection{Determination of Membrane and Fouling Resistances}

The permeate of water flux $\left(J_{w}\right)$ at different $\Delta P$ of clean membrane were measured. The slope of the linear relationship of $\Delta P$ versus $J_{w}$ were determined and used to calculate $R_{m}$ resistance according to Darcy's law:

$$
J_{w}=\frac{\Delta P}{\mu R_{m}}
$$

The fouling resistance $\left(R_{f}\right)$, including reversible fouling $\left(R_{r f}\right)$ and irreversible fouling $\left(R_{i f}\right)$ determination was similar to those of hydraulic membrane resistance but the slope obtained was $1 /\left(\mu\left(R_{m}+R_{f}\right)\right.$. After that, the reversible fouling was removed by back washing. The fouled membrane was turned over and filtration was performed with distilled water at $\triangle P 200 \mathrm{kPa}$ until the steady flux obtained. Then the irreversible fouling was determined and the slope obtained was $1 /\left(\mu\left(R_{m}+R_{i f}\right)\right.$. The reversible fouling was the difference of fouling and irreversible fouling resistances and can be calculated using the following equation:

$$
R_{f}=R_{r f}+R_{i f}
$$




\subsection{Chemical Composition and Physical Properties Analysis}

The chemical composition and physical properties analysis of fresh and clarified wine samples taking during the experiments were performed using the following methods. Total solids (TS) and total soluble solid (TSS) were determined by gravimetric method and refractometer respectively. Protein content was analyzed by using Lowery method. Citric and acetic acid were analyzed by titration method. Alcohol content was determined by using Ebulliometer (Dujardin-Selleron). Viscosity was determined by U-tube (model AVS-Mebstative). Density was determined by Gravimetric method. Turbidity was analyzed by determination of absorbance at $340 \mathrm{~nm}$ using a spectrophotometer (Jasco, model 530). Color was determined by using Hunter Lab (ColorFlex, model ColorQuest XT) and pH was determined by using $\mathrm{pH}$ meter (Mettler, model Delta 320).

\subsection{RESULTS AND DISCUSSION}

\subsection{Fresh Wine and Clarified Wine Characteristics}

The chemical composition and physical properties of fresh wine and clarified wine obtained by using different membranes are shown in Tables 1 and 3 respectively. There was no significant difference in the alcohol content of fresh wine and clarified wine. They were about 9.6 to $10.8 \%$ slightly lower than those of grapes and sherry wine [6]. The protein content in fresh wine was $17.8 \mathrm{mg} / \mathrm{l}$ and reduced to $16.3,15.0,14.2$ and $10.7 \mathrm{mg} / \mathrm{l}$ for clarified wine obtained by using $0.45 \mathrm{~mm} \mathrm{MCE}, 0.22$ $\mu \mathrm{m}$ MCE, $0.22 \mu \mathrm{m}$ MPDVF and $0.22 \mu \mathrm{m}$ PESF respectively. Similarly to protein transmission, both total solid and total soluble solid content of fresh wine and clarified wine were significantly different. These results suggested that not only membrane pore size but also other properties, probably linked to membrane fouling involved in transmission of protein and solid. Acetic acid and citric acid content in the fresh wine were 0.06 and $0.25 \%$ respectively. The result clearly shown that acetic acid and citric acid content in clarified wine using $0.45 \mu \mathrm{m} \mathrm{MCE}, 0.22 \mu \mathrm{m}$ MCE, and $0.22 \mu \mathrm{m}$ MPDVF were not different from those in fresh wine. The density of clarified wine was slightly decreased compared to that of fresh wine. The viscosity of clarified wine was lower than that of fresh wine. This may be due to a reduction of total solid, total soluble solid and protein. According to the absorbance, wine turbidity was significantly affected by microfiltration. The membrane having a larger pore size tend to give less brightness wine compared to those of smaller pore size. In addition, the color of fresh and clarified wine, expressed with the value of Hunter L (lightness), a (redness) and b (yellowness) are also shown in Tables 1 and 3 . Hunter $L$ values of clarified wine were not different from that of fresh wine. The redness (a value) of all clarified wine samples were higher than that of fresh wine. The yellowness (b value) of fresh wine and clarified wine using $0.45 \mu \mathrm{m} \mathrm{MCE}, 0.22 \mu \mathrm{m} \mathrm{MCE}, 0.22 \mu \mathrm{m}$ MPDVF and $0.22 \mathrm{~mm}$ were $6.36,6.06,5.85$ and 5.7 respectively. This result indicated that microfiltration, membrane pore size and hydrophobicity had a significant effect on yellowness reduction. The $\mathrm{pH}$ of fresh and clarified wine were in the range of 3.1-3.3.

\subsection{Flux Behavior}

The permeate flux during dead-end filtration of pineapple wine using different types of microfiltration membrane are shown in Figure 1. The initial flux (at the first 30 second of filtration) of $0.45 \mu \mathrm{m} \mathrm{MCE}$ was the highest $(4600 \mu \mathrm{m} / \mathrm{s})$ followed by $0.22 \mu \mathrm{m} \mathrm{MCE}(1940 \mu \mathrm{m} / \mathrm{s}), 0.22 \mu \mathrm{m}$ MPDVF $(1200 \mu \mathrm{m} / \mathrm{s})$ and $0.22 \mu \mathrm{m}$ PESF $(154 \mu \mathrm{m} / \mathrm{s})$ respectively. The higher initial permeate flux followed by a rapid decline in permeate flux of the larger pore membrane was expected. A rapid decline in permeate flux 


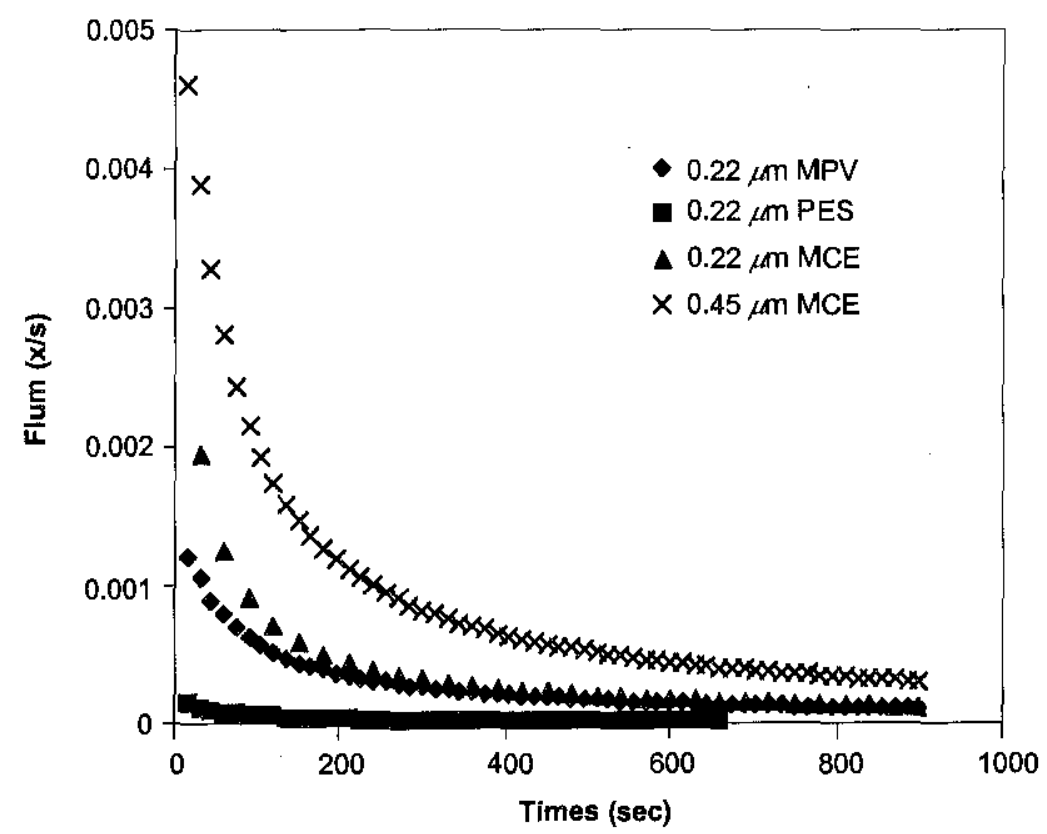

Figure 1 Permeate flux during dead-end microfiltration of pineapple wine (at $\Delta P=200 \mathrm{kPa}$ and temperature $=25^{\circ} \mathrm{C}$ )

Table 3 Composition and physical properties of clarified pineapple wine

\begin{tabular}{|c|c|c|c|c|}
\hline & $0.45 \mu \mathrm{m} \mathrm{MCE}$ & $0.22 \mu \mathrm{m}$ MCE & $0.22 \mu \mathrm{an}$ MPVDF & $0.22 \mu \mathrm{m}$ PESF \\
\hline$\%$ Alcohol & $10.9 \pm 0.2$ & $9.6 \pm 0.4$ & $10.1 \pm 0.2$ & $10.1 \pm 0.1$ \\
\hline Protein(mg/l) & $16.3 \pm 1.5$ & $15.0 \pm 1.3$ & $14.2 \pm 0.6$ & $10.7 \pm 0.2$ \\
\hline Citric acid (\%) & $0.24 \pm 0.01$ & $0.25 \pm 0.00$ & $0.24 \pm 0.00$ & ND \\
\hline Acetic acid (\%) & $0.06 \pm 0.00$ & $0.06 \pm 0.00$ & $0.04 \pm 0.00$ & ND \\
\hline Total soluble solid ( $\left.{ }^{\circ} \mathrm{Brix}\right)$ & $6.8 \pm 0.0$ & $7.0 \pm 0.0$ & $6.4 \pm 0.0$ & ND \\
\hline Total solid (mg/ml) & $22.7 \pm 0.7$ & $20.6 \pm 0.6$ & $19.4 \pm 0.6$ & ND \\
\hline Density $\left(25^{\circ} \mathrm{C}\right)(\mathrm{mg} / \mathrm{ml})$ & $996 \pm 1$ & $988 \pm 1$ & $992 \pm 1$ & $990 \pm 1$ \\
\hline Viscosity $\left(25^{\circ} \mathrm{C}\right)(\mathrm{mPa} . \mathrm{s})$ & $1.31 \pm 0.02$ & $1.24 \pm 0.01$ & $1.25 \pm 0.01$ & $1.21 \pm 0.01$ \\
\hline $\mathrm{pH}$ & $3.2 \pm 0.0$ & $3.2 \pm 0.0$ & $3.1 \pm 0.0$ & ND \\
\hline Turbidity (absorbance at $340 \mathrm{~nm}$ ) & $1.35 \pm 0.00$ & $1.25 \pm 0.00$ & $1.26 \pm 0.00$ & $1.18 \pm 0.00$ \\
\hline \multicolumn{5}{|l|}{ Color } \\
\hline L (lightness) & $98.80 \pm 0.20$ & $100.10 \pm 0.00$ & $99.2 \pm 0.00$ & $100.43 \pm 0.00$ \\
\hline A (redness) & $-1.38 \pm 0.01$ & $-1.05 \pm 0.00$ & $-0.45 \pm 0.06$ & $-1.33 \pm 0.00$ \\
\hline B (yellowness) & $6.09 \pm 0.03$ & $6.06 \pm 0.01$ & $5.85 \pm 0.04$ & $5.70 \pm 0.01$ \\
\hline
\end{tabular}

ND : Non-quantiable

for large pore size membrane was also expected for those solution containing protein or small particle [7]. This can be explained by membrane fouling, forming on the top of membrane surface and/or inside the membrane pore. The permeate flux of $0.22 \mu \mathrm{m} \mathrm{MCE}$, and $0.22 \mu \mathrm{m} \mathrm{MPDVF}$ were similar. However, the permeate flux of $0.22 \mu \mathrm{m}$ PESF was much lower than those of $0.22 \mu \mathrm{m} \mathrm{MCE}$ and 0.22 
$\mu \mathrm{m}$ MPDVF, having the same pore size. Both $0.22 \mu \mathrm{m}$ MCE, and $0.22 \mu \mathrm{m}$ MPDVF are hydrophilic membranes while $0.22 \mathrm{rm}$ PESF is hydrophobic membrane. It is known that membrane fouled by protein is less compared to that of hydrophobic membrane [7]. Thus according to this result and protein transmission result (Tables 1 and 3), possibly protein played an important role in membrane fouling during pineapple wine filtration.

\subsection{Cake Formation}

The relationships between $t / V$ and $V$ for all membranes were plotted as shown in Figure 2 and the cake filtration volume and specific cake resistance were determined and the results are shown in Table 4 . The cake filtration volume $\left(V_{c}\right)$ is the minimum accumulative volume of permeate, where the cake begins to form on the membrane surface. For the dead-end microfiltration process, it is accepted that the cake layer, on the top of membrane surface is often formed at the final period of filtration [8]. At the beginning of filtration, membrane can be fouled by different possible mechanisms, e.g. pore blocking, pore narrowing, depending on membrane and feed properties as well as processing conditions [4]. For this study, the cake filtration volume, therefore, suggested the role of membrane properties on membrane fouling. The cake filtration volume was estimated as indicated in Figure 2. The relationship between $t / V$ and $V$ of $0.45 \mu \mathrm{m} \mathrm{MCE} \mathrm{(Figure} \mathrm{2(a)),} 0.22 \mu \mathrm{m} \mathrm{MCE} \mathrm{(Figure} \mathrm{2(b))} \mathrm{and}$ $0.22 \mu \mathrm{m}$ MPDVF (Figure $2(\mathrm{c}))$ membranes were similar. At the beginning of filtration, the value of $t / V$ increased slightly as the accumulative permeate volume increased. During this period, it was possible that membrane was fouled due to pore blocking or pore narrowing as suggested by [6]. The cake filtration volume was obtained where the value of $t / V$ increased sharply as the accumulative permeate volume increased. For $0.22 \mu \mathrm{m}$ PESF, the different shape of curve was observed (Figure 2(d)). Since there was no sharp increased of $t / V$ versus $V$ plot, it was possible that no cake layer was formed. PESF is hydrophobic, therefore, protein and possibly other molecules, e.g. polysaccharide were rapidly adsorbed on the top membrane surface and/or inside membrane pore at the beginning of the process, causing a severe fouling, leading to a lower transmission of protein, total solid and total soluble solid (Tables 1 and 3). In addition, total volume of filtrate after 10 minutes of filtration was $18 \mathrm{ml}$, about 10 times less than those of $0.22 \mu \mathrm{m} \mathrm{MCE}$ and $0.22 \mu \mathrm{m}$ MPDVF, thus fewer amounts of molecules and particles retained in the retentate, unlikely to form the cake were expected.

The cake filtration volume of $0.45 \mu \mathrm{m}$ MCE, $0.22 \mu \mathrm{m} \mathrm{MCE}$, and $0.22 \mu \mathrm{m}$ MPDVF were 435,129 and 126 respectively. The specific cake resistances, represented by the term of $\alpha C_{s}$ were $0.55,5.85$ and 6.14 for $0.45 \mu \mathrm{m} \mathrm{MCE,} 0.22 \mu \mathrm{m} \mathrm{MCE}$ and $0.22 \mu \mathrm{m}$ MPDVF respectively. Both cake filtration volume and specific cake resistance of $0.22 \mu \mathrm{m}$ PESF could not be determined since no cake layer was formed as discussed earlier. These results suggested the influence of membrane pore size and hydrophobicity and may be the role of protein on membrane fouling. For the large pore size membrane

Table 4 Comparison of cake formation volume $\left(V_{c}\right)$, specific cake resistance $\left(\alpha C_{s}\right)$, fouling resistance $\left(R_{f}\right)$, reversible fouling resistance $\left(R_{f}\right)$ and irreversible fouling resistance $\left(R_{i f}\right)$ in microfiltration of pineapple wine using different types of membrane

\begin{tabular}{lcclll}
\hline Type of membrane & $\boldsymbol{V}_{\boldsymbol{c}}(\mathrm{ml})$ & $\alpha \boldsymbol{C}_{s}\left(\mathrm{~m}^{-\mathbf{2}}\right)$ & $\boldsymbol{R}_{\boldsymbol{f}}\left(\mathrm{nm}^{-\mathbf{1}}\right)$ & $\boldsymbol{R}_{\boldsymbol{f}}\left(\mathrm{nm}^{-\mathbf{1}}\right)$ & $\boldsymbol{R}_{\boldsymbol{f f}}\left(\mathrm{nm}^{-\mathbf{1}}\right)$ \\
\hline $0.45 \mu \mathrm{m} \mathrm{MCE}$ & $435 \pm 91$ & $0.55 \pm 0.09$ & $0.8 \pm 0.0$ & $0.6 \pm 0.1$ & $0.20 \pm 0.1$ \\
$0.22 \mu \mathrm{m} \mathrm{MCE}$ & $129 \pm 29$ & $5.85 \pm 0.48$ & $26.7 \pm 11.7$ & $25.7 \pm 12.0$ & $1.0 \pm 0.3$ \\
$0.22 \mu \mathrm{mMPVDF}$ & $126 \pm 16$ & $6.14 \pm 0.26$ & $28.4 \pm 10.1$ & $27.4 \pm 10.5$ & $1.0 \pm 0.4$ \\
$0.22 \mu \mathrm{mPESF}$ & - & - & $68.2 \pm 23.7$ & $64.9 \pm 24.1$ & $3.3 \pm 0.4$ \\
\hline
\end{tabular}


$(0.45 \mu \mathrm{m} \mathrm{MCE})$ in which the highest transmission of total solid, total soluble solid and protein was found, less solute or particle was retained on the membrane surface, resulting in a higher cake filtration volume. In addition, the specific cake resistance for $0.45 \mu \mathrm{m} \mathrm{MCE} \mathrm{was} \mathrm{the} \mathrm{lowest,} \mathrm{suggesting} \mathrm{that}$ the large particles were a major component, formed the cake layer. For $0.22 \mu \mathrm{m} \mathrm{MCE}$, and $0.22 \mu \mathrm{m}$ MPDVF, both cake filtration volume and specific'cake resistance were similar since they had the

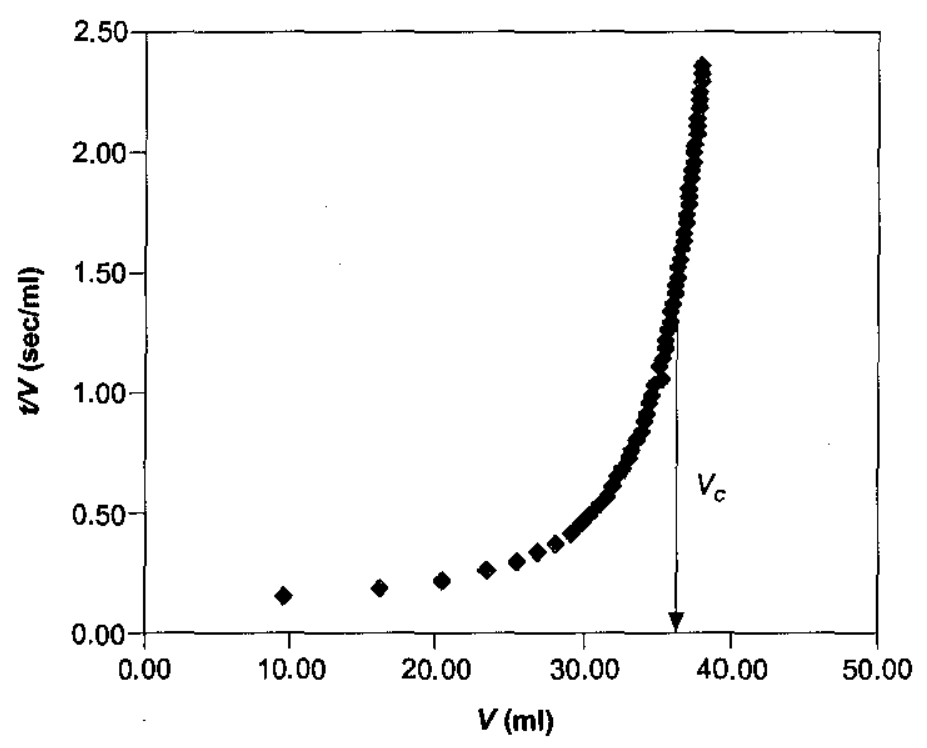

(a) $0.45 \mu \mathrm{m} \mathrm{MCE}$

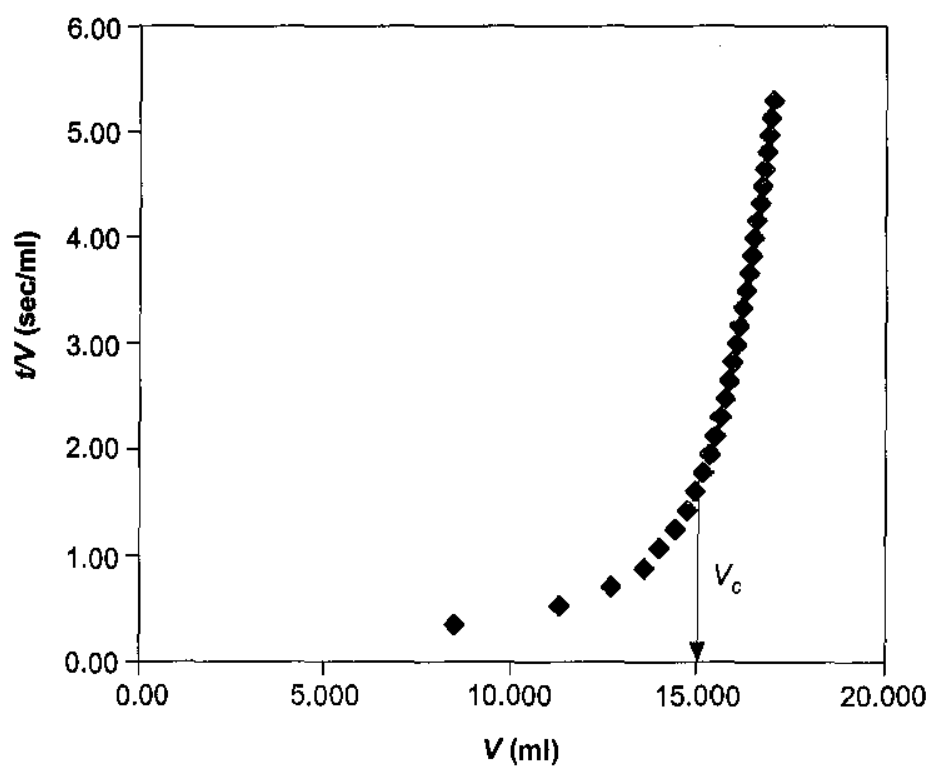

(b) $0.22 \mu \mathrm{m} \mathrm{MCE}$ 


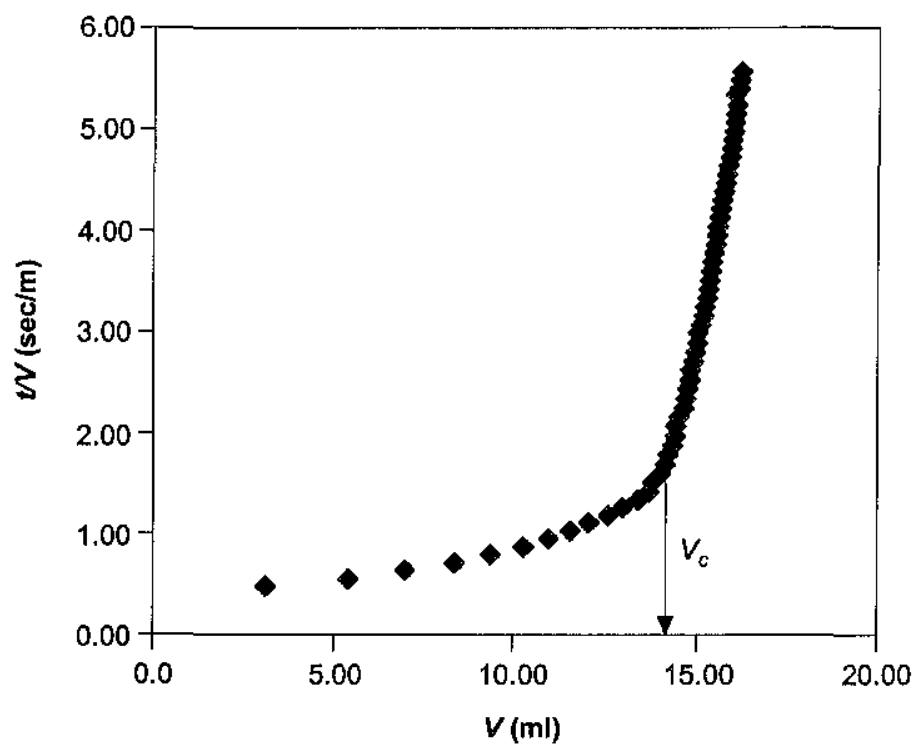

(c) $0.22 \mu \mathrm{m}$ MPVDF

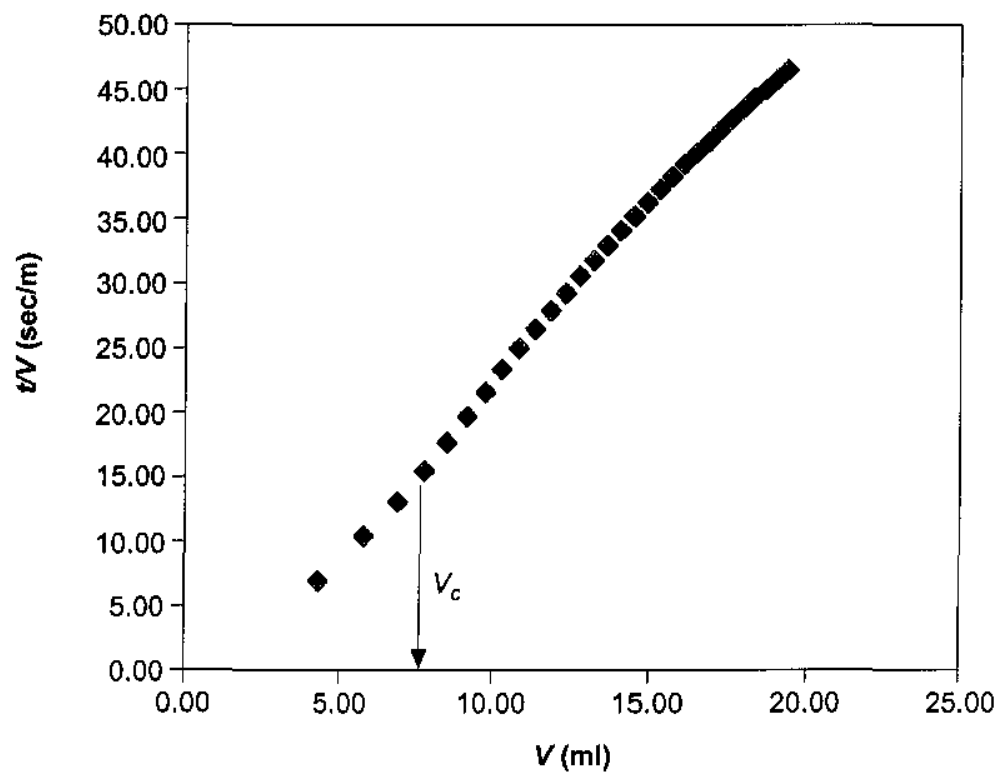

(d) $0.22 \mu \mathrm{m}$ PESF

Figure 2 The ratio of filtration time to permeate volume $(t / V)$ vs. permeate volume $(V)$ for microfiltration of pineapple wine (at $\Delta P=200 \mathrm{kPa}$ and temperature $=25^{\circ} \mathrm{C}$ ): (a) $0.45 \mu \mathrm{m} \mathrm{MCE}$, (b) $0.22 \mu \mathrm{m} \mathrm{MCE}$, (c) $0.22 \mu \mathrm{m}$ MPVDF, (d) $0.22 \mu \mathrm{m}$ PESF 
same pore size and hydrophilicity. Large particles, protein and other small molecules may be responsible for those values, thus less porosity of cakè layer was formed, as suggested by Goncalves [1].

\title{
3.4 Fouling Behavior
}

The fouling resistance $\left(R_{f}\right)$, reversible fouling resistance $\left(R_{r f}\right)$ and irreversible fouling resistance $\left(R_{i f}\right)$ of fouled membranes are shown in Table 4 . In general $R_{f}, R_{r f}$ and $R_{i f}$ of $0.22 \mu \mathrm{m}$ PESF were the highest followed by those values of $0.22 \mu \mathrm{m}$ MPDVF, $0.22 \mu \mathrm{m}$ MCE and $0.45 \mu \mathrm{m}$ MCE respectively. The $R_{f}$ of $0.22 \mathrm{~mm}$ PESF was approximately 80 times of the lowest values $(0.45 \mu \mathrm{m} \mathrm{MCE})$ and about 2.5 times of those values of $0.22 \mu \mathrm{m} \mathrm{MCE,} 0.22 \mu \mathrm{m}$ MPDVF. For all membranes, the major fouling were reversible. The ratio of irreversible fouling to reversible fouling resistances $\left(R_{i f} / R_{f}\right)$ of $0.45 \mu \mathrm{m}$ MCE was about $25 \%$ while the ratio of $R_{i f} / R_{f}$ for $0.22 \mu \mathrm{m} \mathrm{MCE,} 0.22 \mu \mathrm{m}$ MPDVF and $0.22 \mu \mathrm{m}$ PESF were in the range of 4-5\%. A higher ratio of $R_{i f} / R_{f}$ for a larger pore size membrane $(0.45 \mu \mathrm{m} \mathrm{MCE})$ could be due to the internal fouling (e.g. pore blocking, pore narrowing), as suggested by Marshall et al.[7]. The interaction between membrane and wine components, especially protein and polysaccharide played an important role in membrane fouling, both reversible and irreversible [6]. In addition, fouling resistances of MCE and MPVDF were in agreement with the specific cake resistance (also see Table 4). The average size of particles in the cake layer of sherry wine varied from 10 to $50 \mathrm{~nm}$, depending on wine properties [9]. The fouling resistance increased as the specific cake resistance increased. The results of this study indicated the influence of membrane hydrophobicity and pore size as well as protein and other components in the pineapple wine on membrane fouling and its reversibility.

\subsection{CONCLUSION}

The pineapple wine was successfully clarified by microfiltration. The composition and quality of clarified wine were similar to those of fresh wine. The turbidity and yellowness of fresh wine was reduced by microfiltration. The membrane pore size and hydrophobicity played an important role in determination of cake filtration volume, specific cake resistance and membrane fouling during pineapple wine microfiltration. The membrane with large pore size $(0.45 \mathrm{~mm} \mathrm{MCE})$ gave the highest cake filtration volume and the lowest fouling and specific cake resistance. The hydrophobic membrane $(0.22 \mu \mathrm{m}$ PESF) gave the highest fouling resistance (both reversible and irreversible). For small particles and macromolecules, e.g. polysaccharide, protein possibly was responsible for the results obtained. Regarding the permeate flux and fouling, the best membrane material seemed to be the hydrophilic membrane $(0.45 \mathrm{~mm}, \mathrm{MCE})$, the most suitable membrane for clarification of pineapple wine. However, an intensive organoleptic test with pilot scale would be needed with regards to wine quality.

\section{NOMENCLATURES}

\author{
A : Membrane area $\left(\mathrm{m}^{2}\right)$ \\ $C_{s} \quad$ : Mass of solid per volume of filtrate $\left(\mathrm{kg} / \mathrm{m}^{3}\right)$ \\ $J_{w} \quad:$ Water flux $\left(\mathrm{m}^{3} / \mathrm{m}^{2} \mathrm{~s}\right)$ \\ $\Delta P \quad:$ Transmembrane pressure $(\mathrm{Pa})$
}


$R_{m} \quad$ : Hydraulic membrane resistance $\left(\mathrm{m}^{-1}\right)$

$R_{f} \quad$ : Fouling resistance $\left(\mathrm{m}^{-1}\right)$

$R_{r f} \quad$ : Reversible fouling resistance $\left(\mathrm{m}^{-1}\right)$

$R_{i f} \quad$ : Irreversible fouling resistance $\left(\mathrm{m}^{-1}\right)$

$t \quad$ : Filtration time (sec)

$V \quad$ : Permeate volume $\left(\mathrm{m}^{3}\right)$

$V_{c} \quad$ : Cake filtration volume $\left(\mathrm{m}^{3}\right)$

$\alpha \quad:$ Specific cake resistance $(\mathrm{m} / \mathrm{kg})$

$\mu \quad$ : Viscosity (Pa.s)

\section{ACKNOWLEDGEMENTS}

The second and third authors would like to thank the faculty of Agro-industry and Prince of Songkla University for the financial support.

\section{REFERENCES}

[1] Goncalves, F., C. Fernandes, and M. N. Pinho. 2001. White Wine Clarification by Micro/ ultrafiltration: Effect of Removing Colloids in Tartaric Stability. Sep. Purif. Technol. 22-23: 423-429.

[2] Urkiaga, A., L. D. Fuentes, and M. Acilu. 2002. Membrane Comparison for Wine Clarification by Microfication. Desalination. 148: 115-120.

[3] Bellevillle, M. P., J. M.,Brillouet, T. Fuente, and M. Moutounet. 1990. Polysaccharide Effects on Cross-flow Microfiltration of Two Red Wines with Microporous Aluminar Membrane. J. Food Sci. 55: 1598

[4] Vernhet, A., and M. Moutounet. 2002. Fouling of Organic Microfiltration Membranes by Wine Constituents: Importance, Relative Impact of Wine Polysaccharides and Polyphenols and Incidence of Membrane Properties. J. Membrane Sci. 201: 103-122.

[5] Zeman, L. J., and A. L. Zydney. 1996. Microfiltration and Ultrafiltration Principles and Application. New York: Marcel Dekker, Inc.

[6] Vernhet, A., D. Cartalade, and M. Moutounet. 2003. Contribution to the Understanding of Fouling Build-up During Microfiltration of Wines. J. Membrane Sci. 211: 357-370.

[7] Marshall, A. D., P. A. Munro, and G. Tragardh. 1993. The Effect of Protein Fouling in Microfiltration and Ultrafiltration on Permeate Flux, Protein Retention and Selectivity: A Literature Review. Desalination. 91: 65-108.

[8] Riedl, K., B. Girard, and R. W. Lencki. 1998. Interaction Responsible for Fouling Layer Formation During Apple Juice Clarification. J. Agric. Food Chem. 46: 2458-2464.

[9] Palacios, V. M., and I. C. Perez. 2002. Comparative Study of Crossflow Microfiltration with Conventional Filtration of Sherry Wine. J. Food Eng. 54: 95-102. 